\title{
Człowiek jako mężczyzna i kobieta. Fundamenty antropologii biblijnej, ich źródła i konsekwencje
}

\author{
Humanity as Man and Woman. \\ Fundamental Biblical Anthropology, its Sources and Consequences
}

\author{
JANUSZ LEMAŃSKI \\ Uniwersytet Szczeciński \\ lemanski@koszalin.opoka.org.pl, ORCID: 0000-0002-1512-997X
}

\begin{abstract}
Streszczenie: W artykule omówione zostały dwa opisy stworzenia człowieka ( $R d z 1 ; 2-3$ ). Akcent w analizie tych wypowiedzi położony jest na fakt, że w obu opisach podkreśla się, iż człowiek został stworzony jako mężczyzna i kobieta. Dwupłciowa natura człowieka akcentowana jest w nich zarówno w wymiarze biologicznym i religijnym (tak Rdz 1,26-28), jak i społecznym (tak Rdz 2,18-25). Obie płcie są sobie równe w każdym z tych aspektów. Człowiek w całej pełni realizuje swoje powołanie do życia i współpracy z Bogiem dopiero jako mężczyzna i kobieta. Jego zdolność do nawiązywania relacji wyraża się najpełniej w obrębie płciowego zróżnicowania własnego gatunku. Zachodzi to w wymiarze biologicznym (płodność umożliwiająca poddanie sobie ziemi) oraz intelektualnym i duchowym (kobieta jako "odpowiednia pomoc").
\end{abstract}

Słowa kluczowe: człowiek; mężczyzna i kobieta; płeć; Rdz 1-2

Abstract: The article discusses the two descriptions of the creation of man (Gen chap. 1 and chap. 2-3). In analyzing these verses, emphasis is placed on the fact that both descriptions stress that humankind was created as man and woman. The dual-gender nature of mankind is evoked in the two passages in the biological and religious dimensions (Gen 1:26-28) as well as the social (Gen 2:18-25). The two sexes are equal to each other in each of these aspects. People fully achieve their calling to live and cooperate with God only as a man and a woman. One's ability to establish relationships is most fully expressed only within the sexual diversity of our species. This occurs in the biological dimension (fertility enabling us to subdue the earth) as well as the intellectual and spiritual (woman as the "suitable helper").

Keywords: man, man and woman, sex, Gen 1-2

Choć tematy antropologiczne i elementy składowe samej antropologii biblijnej odnaleźć można w różnych miejscach Biblii, to fundamentów dla zrozumienia biblijnej koncepcji człowieka w Starym Testamencie szukać należy niewątpliwie w trzech pierwszych rozdziałach Księgi Rodzaju. Przez długi czas dzielono je na tekst kapłański $(\operatorname{Rdz} 1,1-2,3=\mathrm{P})$ i nie-kapłański (Rdz 2-3[4] = nie-P), wskazując zarazem, że w obu tych tekstach znajdujemy dwie różniące się pomiędzy sobą koncepcje antropologiczne. Różnice te wynikały - jak słusznie sądzono - z odmiennego czasu i środowiska, w jakim oba teksty powstały, przy czym dominowało uzasadnione 
przekonanie, że Rdz 2-3[4] jest tekstem znacznie starszym i bliższym koncepcyjnie „tradycyjnej bliskowschodniej antropologii”, zaś tekst Rdz 1 stanowi pewnego rodzaju innowację antropologiczną (każdy człowiek jako imago Dei) zrodzoną w wyniku doświadczenia z okresu wygnania babilońskiego i zaistniałych po nim nowych realiów społeczno-politycznych (brak rodzimej monarchii i króla; kształtowanie się teokratycznej wspólnoty wokół świątyni i powstającej stopniowo Tory). Dziś sposób podejścia do obu tych tekstów jest mniej dychotomiczny. Nie ignorując dotychczasowych przekonań o odmienności środowiskowej i koncepcyjnej istniejącej pomiędzy oboma tekstami, podkreśla się obecnie z jednej strony fakt, że nie stanowią one jedynie prostego zestawienia ze sobą jakichś dwóch odmiennych koncepcji antropologicznych, lecz pozostają ze sobą w ścisłej korelacji i „dialogu”, a z drugiej - że teksty te powstawały etapami i znaleźć w nich można co najmniej kilka warstw redakcyjnych, na czele z ostatnią lub jedną z ostatnich, która wprowadziła wspomnianą korelację. Niewątpliwie tym, co o niej stanowi, jest najpierw kapłańska koncepcja człowieka stworzonego na „obraz i podobieństwo” Boga. Z jednej strony jest ona efektem poszerzenia idei imago Dei i przeniesienia jej z samego tylko króla na wszystkich ludzi, a z drugiej stanowi efekt coraz bardziej dominujących przekonań o potrzebie anikonicznego kultu Boga w Izraelu. Proces wprowadzania tych zmian dokonał się w środowisku kapłańskim (P), ale kolejne redakcje Sześcio- czy ostatecznie Pięcioksięgu podjęły się z czasem korekty tej koncepcji, co widoczne jest w ostatecznym kształcie Rdz 2-3[4] $]^{1}$. Z drugiej strony wspomniany proces redagowania pierwszych rozdziałów Księgi Rodzaju nie pozostał bez wpływu również na finalny kształt tekstu kapłańskiego $(\operatorname{Rdz} 1,1-2,3)^{2}$.

Oba teksty można nazwać „,programowymi”, wytyczają bowiem sposób patrzenia na człowieka i jego rolę w ramach stworzenia ${ }^{3}$. Zwrócenie uwagi na ten „fundament antropologiczny" w kontekście dyskusji nad kwestią podejścia do zjawiska homoseksualizmu wydaje się niezbędne. $Z$ jednej strony bowiem mamy teksty stawiające tego typu zachowania w złym świetle lub wręcz ich zabraniające, i rodzi się pytanie o rzeczywiste przyczyny takiej ich deprecjacji, a z drugiej strony teksty biblijne poświęcone tej kwestii interpretowane są jako coś wymagającego aktualizacji lub nowego rozumienia. Wskazuje się przy tym na brak jakiś wyraźnych odniesień do tego typu zachowań w nauczaniu Jezusa lub tłumaczy negatywny do nich stosunek brakiem „pozytywnych doświadczeń" i „prawdziwej miłości” w czasach biblijnych (tak na przykład wypowiedzi św. Pawła), a wreszcie także dawnym kontekstem kulturowym czy kontekstem czysto rytualnym (tak zakazy z Księgi Kapłańskiej) ${ }^{4}$. Przypomnienie fundamentów antropologicznych, pomijanych często w tego rodzaju dyskusjach,

\footnotetext{
Na ten temat szczegółowo por. Lemański, „Imago Dei”, 121-154.

Por. Lemański, „Rdz 1,1-2,3 na nowo odczytane?”, 75-81.

Lemański, „Bóg stwarza”, 13-42.

Na ten temat szerzej w: Lemański, Księga Rodzaju. Rozdziały 11,27-36,43, 393-404 [Ekskurs: „Biblia a kwestia homoseksualizmu"].
} 
wydaje się więc niezbędne, gdyż autorzy biblijni to je właśnie musieli mieć najpierw na uwadze, zanim jeszcze decydowały o ich podejściu do tego zagadnienia względy kulturowe, społeczne czy rytualne.

\section{Kapłańska koncepcja antropologiczna (Rdz 1,26-31)}

Autorzy kapłańscy w ostatecznej wersji swojej „relacji o stworzeniu” przyjęli schemat siedmiodniowy $(6+1)$. Opis stworzenia człowieka umieszczony jest w nim jako drugie dzieło Boga dokonane szóstego dnia. W P nie chodzi tylko o oderwany od reszty opis powołania do życia stworzeń lądowych i człowieka, ale o swoiste zwieńczenie dzieła stworzenia (por. w. 31 i podsumowanie całości jako „bardzo dobre”). Takie wieńczące całość usytuowanie kreacji człowieka pozycjonuje go jako kogoś wyjątkowego i kluczowego w ramach dzieła stworzenia. Nie dziwi zatem, że w tym właśnie tekście dostrzega się podstawy teologicznego wymogu szanowania godności każdego człowieka, bez względu na jego płeć, pochodzenie, kolor skóry czy status społeczny ${ }^{5}$.

W samym opisie znajdujemy typową dla P sekwencję: rozkaz (w. 26) i jego wykonanie (w. 27). Potem już jednak w detalach pojawiają się liczne ewenementy. Wszystkie one służą podkreśleniu tego, kim jest w istocie człowiek w ramach całego stworzenia i kim jest on dla/wobec Boga. Najpierw więc zwraca uwagę liczba mnoga we wprowadzeniu do aktu stworzenia (tzw. kohortativus): „Uczyńmy człowieka...” (w. 26a). Znaczenie tego pluralis jest przedmiotem debaty ${ }^{6}$. W ramach wspomnianego siedmiodniowego schematu pojawia się on wyłącznie w tym miejscu. Dotąd i później (wyłączając $\operatorname{Rdz} 3,22 ; 11,7$ ) mowa Boga będzie prezentowana w liczbie pojedynczej. Zmiana ta musi zatem mieć tu jakieś istotne znaczenie. Badacze zwykle dostrzegają w takiej formie wypowiedzi wyraz pewnego rodzaju komunikacji Stwórcy ze swoim otoczeniem (dwór niebieski; por. Iz 6,8). Wśród innych propozycji można jeszcze wyróżnić interpretację liczby mnogiej jako pluralis deliberativus (C. Westermann) lub - w nawiązaniu do „Ducha Bożego” z Rdz 1,2 - jako rodzaj wezwania skierowanego do samego siebie (U. Cassuto ze wskazaniem na 2 Sm 24,14). Większość badaczy uważa jednak, że ta forma wypowiedzi wyraźnie wskazuje, iż Bóg nie jest sam. Problem w tym, że P raczej nie wspomina nigdy o dworskim otoczeniu Boga. Niemniej opis „(wniebo)wzięcia” Henocha (Rdz 5,24 = P) może sugerować, że tego rodzaju wiedza nie jest mu obca. Idea boskiego dworu pojawia się za to dość często poza tekstami P (por. Ps 29,1-2; 89,6.8), gdzie mowa jest także o „synach Bożych", stanowiących swego rodzaju radę z otoczenia władcy (Ps 89,1; $1 \mathrm{Krl} 22,19-23$ ).

Frevel, „Gottesbildlichkeit”, 255-274.

6 Por. Wenham, Genesis 1-15, 27-28; Hamilton, The Book of Genesis, 132-134; Lemański, Księga Rodzaju. Rozdziały 1-11, 165; Gertz, Das erste Buch, 61. 
Wspomina się potem o nich także jako bytach obecnych przy stwarzaniu świata (por. Hi 38,7). W tym samym duchu zapewne myślał autor drugiego opisu stworzenia, gdy wyrażał "boskie obawy”, aby człowiek nie stał się „podobny do nas” $(\operatorname{Rdz} 3,22)$ w kwestii nieśmiertelności. Za takim komunikatywnym rozumieniem formuły wypowiedzi w liczbie mnogiej przemawia także tradycja bliskowschodnia, umieszczająca stworzenie człowieka w kontekście narady bogów ${ }^{7}$.

Człowiek określony jest przez P mianem 'ādām. Chodzi o rzeczownik mający zasadniczo znaczenie kolektywne - „ludzie”. W P jednak zaczyna on funkcjonować jako określenie jednostki (por. Rdz 5,1a.3.4), a z czasem wręcz jako imię własne (Rdz 5,2). Początkowo mimo wszystko wydaje się on zachowywać swoje pierwotne, kolektywne znaczenie (tak Rdz 1,27-30; Rdz 7; 9). Czy to oznacza pewnego rodzaju ewolucję znaczeniową w ramach szkoły kapłańskiej? Niektórzy badacze sugerują że P mógł myśleć początkowo o pewnego rodzaju prototypie człowieka, podobnie zresztą jak i o prototypach innych żywych stworzeń. W konsekwencji - jeśli przyjać tę sugestię - to 'ādām mogło w pierwotnej wersji opisu stanowić określenie męskiego prototypu, który stwarza sam siebie. Wraz z Rdz 5,1.3-5, a więc z tekstem P, który oryginalnie prawdopodobnie następował zaraz za opisem stworzenia człowieka, w istocie taka sekwencja zdarzeń jest możliwa. Niemniej zauważamy w tym tekście także proces indywidualizacji człowieka, zwłaszcza w wierszu drugim, gdzie Adam funkcjonuje już jako imię własne. Zmiana mogła dokonać się pod wpływem lub w konsekwencji połączenia Rdz 1 z Rdz 2-3, gdzie człowiek opisany jest jako mężczyzna i kobieta $\mathrm{w}$ aspekcie społecznym. W istocie bowiem ostatecznie dla $\mathrm{P}$ człowiek to mężczyzna i kobieta, która - w jednakowym wymiarze jak jej męski odpowiednik - rozumiana jest jako „reprezentantka Boga” na ziemi. Bez niej niemożliwe jest wypełnienie zadań wyznaczonych człowiekowi. W aktualnej wersji $\mathrm{P}$ myśli zatem ostatecznie o „prototypowej” pierwszej parze9. Tylko w taki sposób środowisko to może przedstawić potem, w ramach swoich genealogii, przynależność wszystkich ludzi do jednego gatunku.

W kanonicznej wersji tekstu człowiek zostaje stworzony przez Boga jako imago Dei (ww. 26a.27a), któremu zostaje przekazana władza na ziemi i nad zwierzętami (ww. 26b.28). To przywilej i zarazem zadanie. Człowiek ukazany jest jako stworzenie jednogatunkowe (inaczej niż zwierzęta), ale charakteryzuje go dwupłciowość jego natury (w. 27b) (inaczej niż Bóg). Wszystkie te trzy elementy razem stanowią fundamenty kapłańskiej koncepcji antropologicznej ${ }^{10}$, i to im chcemy teraz przyjrzeć się bliżej.

\footnotetext{
Mayer, „Ein Mythos”, 55-68.

Tak Krüger, „Genesis 1:1-2:3”, 133.

Krüger, „Genesis 1:1-2:3”, 137.

Por. Gertz, Das erste Buch, 63-73.
} 


\subsection{Imago Dei}

Najpierw trzeba zaznaczyć, że chodzi o koncepcję absolutnie unikatową w całej Biblii Hebrajskiej, charakterystyczną wyłącznie dla $\mathrm{P}$, i to tylko w ramach przypisywanej tej szkole wersji prehistorii (por. jeszcze Rdz 5,1; 9,6 = P). Pewne podobieństwa $z$ tą koncepcją wykazuje jedynie Ps 8,5-9. Kwestia pochodzenia i znaczenia tej idei była już przedmiotem licznych analiz ${ }^{11}$. Dziś można mówić o względnym konsensusie w rozumieniu dwuczłonowego zwrotu $b^{e} s a$ lmēn $\hat{u}$ kidmûtēnû. Partykuły $b^{e} \mathrm{i} k^{e}$ bez wątpienia wskazują tu na porównanie, a nie odwzorowanie ${ }^{12}$. W obu leksemach nie chodzi potem o żadną kwalifikację człowieka (tak Ireneusz z Lyonu w II w. po Chr.: odpowiednio naturalne i nadnaturalne uzdolnienia człowieka). Hebrajskie șelem (gr. eikōn; łac. imago) i demût (gr. homoiōsis; łac. similitudo) są w istocie bliskoznaczne, a drugie z tych słów służy tu bardziej porównaniu $\left(k^{\mathrm{e}}\right)$ uwydatniającemu lepiej pierwszą deklarację, niż złagodzeniu jej wymowy czy tym bardziej podkreśleniu jakiejkolwiek różnicy. Z kolei prepozycja $b^{e} \mathrm{w}$ pierwszym leksemie akcentuje porównywalność obu zestawianych ze sobą rzeczywistości ${ }^{13}$. Rzeczownik șelem oznacza statuę, posąg, stelę, czasem relief lub wyobrażenie czegoś (por. Lb 33,52; $2 \mathrm{Krl}$ 11,18; Dn 2,31-35; $1 \mathrm{Sm}$ 6,5.11), a nawet ryty na ścianie (Ez 23,14) i boskie symbole $\left(\right.$ Am 5,26) ${ }^{14}$. Czynienie tego rodzaju przedstawień Boga było zakazane (Wj 20,4). Zatem określenie człowieka w ten sposób jest czymś niezwykłym. Słowem ṣelem wyraża się jednak nie tyle dokładność reprodukcji, ile sam aspekt skutecznej reprezentatywności ${ }^{15}$, co zresztą znajduje potem potwierdzenie w mezopotamskich i egipskich rytuałach „ożywiania boskich posągów”, zwanych także „rytuałem otwarcia ust”"16, a w samym tekście biblijnym w zastosowanych zaimkach „nasz, Jego”. Według P to już nie jakaś statua wykonana przez człowieka, ale sam człowiek stworzony przez Boga staje się jedynym, żywym obrazem Boga na ziemi.

Rzeczownik $d^{e} m u \hat{t}$ jest pochodną od rdzenia czasownikowego $d m h$ - „być podobnym" i zwykle wskazuje na dokładność szkicu konstrukcyjnego lub budowlanego (por. $2 \mathrm{Krl} \mathrm{16,10;} \mathrm{Ez} \mathrm{1,22-26;} \mathrm{8,2;} \mathrm{10,21).} \mathrm{Wyraża} \mathrm{też} \mathrm{cielesne} \mathrm{lub} \mathrm{figuratywne}$ podobieństwo (Dn 10,16). Wraz z prepozycją kaf stanowi w aktualnej dwuczłonowej konstrukcji część pleonazmu opisującego „coś nam podobnego”. W stosunku

11 Por. Gross, „Die Gottebenbildlichkeit”, 35-48; Lemański, Księga Rodzaju. Rozdziały 1-11, 182-187 [Ekskurs: „Imago Dei”, lit.]; Gross et al., „Image of God”, 885-913; Fischer, Genesis 1-11, 152-153.

12 Por. Rdz 5,3: te same partykuły, ale przypisane odwrotnie użytym rzeczownikom. Zob. Lemański, Księga Rodzaju. Rozdzialy 1-11, 166; Gertz, Das erste Buch, 63.

13 Jenni, Die hebräischen Präpositionen, 84.

14 Hans Wildberger („șelem”, 556-563, zwł. 558) pisze, że te różnorodne (wcześniejsze zastosowania) pokazują, iż „dem Begriff eine beachtenswerte Flexibilität eigen ist”.

15 Schroer, In Israel gab es Bilder, 322-332, zwł. 324: „Representationsbild”; Gross, „Gen 1,26.27”, 11-38, zwł. 19: „machtvolle Repräsentanz”.

16 Temat omówiony dobrze m.in. w: McDowell, The Image of God. Por. także Lemański, „Imago Dei”, 128-129. 
do pierwszego członu akcentuje jedynie bardziej właściwe rozumienie tego podobieństwa. O ile bowiem șelem uprzytamnia fakt, że chodzi o obrazową reprezentatywność, o tyle $d^{e} m \hat{u} t$ wyraża lepiej fakt, że to, co reprezentuje Boga na ziemi, jest najbardziej odpowiednie do wyznaczonej temu roli (por. Iz 40,18) ${ }^{17}$. Tę względną synonimiczność obu pojęć potwierdza także dwujęzyczna (asyryjsko-aramejska) stela z IX w. przed Chr. znaleziona w Tell Fekherije ${ }^{18}$.

W Rdz 1,26-27 znajdujemy więc koncepcję człowieka (jako mężczyzny i kobiety, o czym za chwilę) w roli reprezentanta Boga na ziemi. Reprezentacja ta opisana jest jako obecność w formie „statuy” dobrze odzwierciedlającej istotę swego Stwórcę. Nie chodzi tu jednak - jak już wspomnieliśmy - o podobieństwo fizyczne, ale reprezentacyjno-funkcyjne. Korzeni tej idei nie trudno doszukać się w ideologii królewskiej, ukazującej króla jako reprezentanta i ucieleśnienie Boga na ziemi. Koncepcję tę znano już w starożytnym Egipcie ${ }^{19}$, zwłaszcza w okresie panowania 18. i 19. dynastii (1550-1190 przed Chr. $)^{20}$. W Izraelu i Judzie znana była zapewne już w czasach monarchii (por. 2 Sm 7; potem także Ps $2 ; 20-21 ; 110 ; 132$ ). Autorzy kapłańscy mogli ją więc nie tyle zapoznać, co w nowy sposób podjąć i zmodyfikować jeszcze podczas pobytu na wygnaniu w Babiloniii ${ }^{21}$ lub pod wpływem Persów, którzy uzasadniali aspiracje swoich achemenidzkich królów do władzy na światem poprzez tego rodzaju ideologię zapożyczoną z Egiptu (zwł. Dariusz I - 549-486 przed Chr.)22. Król przedstawiany jest często w tekstach odzwierciedlających tę ideologię boskiego reprezentanta, jako wyznaczony przez najwyższe bóstwo do pilnowania stwórczego porządku na ziemi i panowania nad chaosem. Taki zakres zadań widać już w prologu do Kodeksu Hammurabiego, jak i w wielu innych mezopotamskich tekstach ${ }^{23}$. „Kiedy więc asyryjski król ukazywał się w przedsionku świątyni Assura ozdobiony koroną boga Assura, dla Asyryjczyków było jasnym, że z postacią króla stopił się «przerażający blask» samego Assura"24.

Badacze nie bez powodu zwracają jednak uwagę na to, że ta koncepcja - ograniczona dotąd ideologicznie wyłącznie do władców ${ }^{25}$ - nabiera w P nowego znaczenia i odnosi się teraz do wszystkich ludzi. Zmiana ta zachodzi wraz z końcem panowania

17 Janowski, „Die lebendige Statue Gottes”, 183-214, zwł. 194-195; Gertz, Das erste Buch, 65, przyp.129.

18 TUAT I/6, 634-637. Polskie tłumaczenie i omówienie w: Lemański, „Rdz 1,1-2,3 na nowo odczytane?", 98.

19 Ockinga, Die Gottebenbildlichkeit.

20 Przykład to inskrypcja Tutmozisa III (1490-1436 przed Chr.) z Serabit el Chadim; por. Ockinga, Die Gottebenbildlichkeit, 109.

21 Taka ideologie w Mezopotamii pojawiają się dość obficie już w XIII w. przed Chr. i potem, zwłaszcza w czasach neoasyryjskich, czego przykładem jest tekst z czasów Asarhaddona (681-669 przed Chr.); por. Angerstorfer, „Ebenbild eines Gottes”, 47-58, zwł. 50.

22 Rüterswörden, Dominium terrae, 81-130. Por. TUAT I/6, 610 (Inskrypcja Dariusza I z Suzy).

23 Maul, „Der assyrische”, 65-77.

24 Maul, „Der assyrische”, 77.

25 Wśród nich przywilej ten zyskała także jedna kobieta-faraon: Hatszepsut, opisywana jako obraz boga Re; Ockinga, Die Gottebenbildlichkeit, 146-147; Desroches Noblecourt, Hatszepsut, 134, 136. 
dynastii Dawida, jednak określenie jej mianem „demokratyzacja idei” stanowi pewnego rodzaju przekłamanie. Choć pojęcie demokracji pojawia się już w tym czasie wraz z rozwojem ustroju Aten ${ }^{26}$, to jednak idea ta po pierwsze nie musi być jeszcze znana autorom kapłańskim, a po drugie - w innych wypowiedziach przypisywanych P wyraźnie widać, że środowisko to nie zamierzało ani odrzucać, ani zastępować instytucji monarchii (por. Rdz 17,6; 35,11). Zresztą - jak słusznie zauważają dalej komentatorzy $^{27}$ - nawet w Atenach demokracja nie oznaczała, że władza została dana wszystkim, lecz koncepcja ta ograniczała się jedynie do wolnych obywateli i do tego - do samych tylko mężczyzn. W P takie ograniczenia i wykluczenia zostają wyeliminowane. P nie dokonuje zatem transformacji monarchii w demokrację, a raczej transformuje ideę króla jako obrazu Boga w ideę ludzi w roli takiego obrazu. W ten sposób ideologia królewska staje się fundamentem nowej koncepcji antropologicznej, w której dokonuje się „rojalizacja obrazu człowieka” (niem. Royalisierung des Menschenbild $)^{28}$. Tym razem chodzi o funkcję człowieka jako takiego i jego występowanie w roli reprezentanta Boga poprzez egzekwowanie danej mu władzy nad naturą (ww. 26b.28). To właśnie we właściwym realizowaniu tego zadania wyraża się to podobieństwo człowieka do Boga i być może także dokonuje się legitymizacja tej jego godności ${ }^{29}$. Nie chodzi tu o jakikolwiek nieprzemyślany antropomorfizm, który prowadzi do porównania człowieka z Bogiem, lecz o kwalifikację pewnej ludzkiej właściwości lub danej mu prerogatywy jako „boska”. Nie przynosi tu ujmy samemu Bogu, często zresztą opisywanemu za pomocą antropomorfizmów ${ }^{30}$. Podkreśla za to wyjątkowy status człowieka wśród innych żywych stworzeń.

\subsection{Dominium terrae et regnum animalium}

Ten aspekt (ww. 26b.28) ma swój prolog nieco wcześniej, kiedy Bóg błogosławi morskim stworzeniom i ptakom (w. 22). Ich przestrzeń życiowa (morza i niebiosa) nie stanowi jednak przestrzeni życiowej dla człowieka. Ziemia zaś będzie nią zarówno dla zwierząt lądowych, jak i dla ludzi ${ }^{31}$. Tym razem błogosławieństwo dokonuje się nico inaczej. Stwórca zwraca się bezpośrednio do człowieka, co w konsekwencji odróżnia, według $\mathrm{P}$, tego ostatniego od zwierząt (podobnie potem Bóg przemówi do Noego w Rdz 6-9, Abrahama w Rdz 17 czy Mojżesza w Wj 6; 25-31). Fakt więc, że Bóg wcześniej tylko błogosławił (w. 22), a teraz także „mówi do nich” (w. 28a), wskazuje na możliwość nawiązania relacji personalnej pomiędzy Bogiem a człowiekiem ${ }^{32}$.

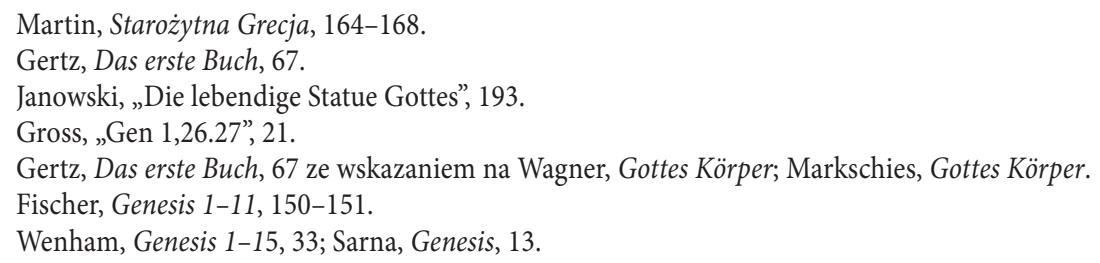


Zatem i błogosławieństwo udzielone ludziom oznacza coś więcej niż to udzielone wcześniej stworzeniom morskim i ptakom (w. 22) ${ }^{33}$. Tym razem chodzi o swoiste wezwanie do dawania świadomej odpowiedzi, dobrowolną współpracę, a nie tylko o naturalny proces prokreacji i biologicznej egzystencji.

Tradycja interpretacyjna użytych tu imperatywów, jak i faktu, że Bóg błogosławi płodność morskich stworzeń i ptaków (w. 22), a nie czyni tego wobec zwierząt lądowych, błogosławiąc jedynie człowieka (w. 28), jest bardzo długa. Owe błogosławieństwo ma tu jednak kluczowe znaczenie, gdyż stanowi siłę do życia ${ }^{34}$, umożliwiającą późniejszą prokreację i wypełnianie nakazu zaludnienia ziemi (por. Rdz 1,28a; 5,1) oraz skuteczny proces dominacji nad nią i nad zwierzętami. Jeśli istniał wcześniej „niezależny dokument P”, to „Księga zrodzeń/potomków Adama” (Rdz 5,1; por. potem Wj 1,7: potomstwo Izraela) znajdować się musiała bezpośrednio po opisie stworzenia człowieka ${ }^{35}$. Współcześni komentatorzy zwracają uwagę na fakt, że zadanie wyznaczone człowiekowi nierozerwalnie powiązane jest $\mathrm{z}$ jego płodnością i zadaniem „napełnienia ziemi” (nie wody!). Istnieje więc pewna granica dla wyznaczonego zadania - napełnienie ziemi. Autor kapłański miał prawdopodobnie przed sobą obraz pustej ziemi, wyludnionej i zrujnowanej wojennymi kataklizmami oraz deportacjami ludności; ziemi opanowanej w znacznej mierze przez dzikie zwierzęta; ziemi, którą trzeba było na nowo zagospodarować ${ }^{36}$. Serii pięciu imperatywów nie należy więc rozdzielać, a nakazu panowania nad ziemią i zwierzętami - odrywać od zadania wynikającego z udzielonego przez Boga błogosławieństwa i gwarantowanej nim płodności. Przy czym podkreślmy, że w tym ostatnim przypadku chodzi wyraźnie o „uzdolnienie”, a nie rozkaz ${ }^{37}$.

Człowiek ma „wziąć tę ziemie w posiadanie” (kbš) i ją „opanować/uczynić sobie poddaną" $(r d h)$. W bardziej obrazowym sensie - ta ziemia ma zostać dosłownie zdeptana ${ }^{38}$. Za pomocą wymienionych czasowników często opisuje się sposób sprawowania władzy. Spór toczy się jedynie o to, czy rozumieć ją w mocniejszym, agresywniejszym sensie: „ujarzmiać, zniewalać, upokarzać”, czy raczej w łagodniejszym znaczeniu: „panować, opiekować się, strzec”39. Poddanie sobie ziemi czyniłoby

33 Fischer, Genesis 1-11, 155.

34 Lemański, Księga Rodzaju. Rozdziały 1-11, 170-171.

35 Z dużym prawdopodobieństwem należy również zakładać, że rytmiczna struktura tekstu $(6+1)$ pojawiła się wtórnie ze względu na dodanie do niego w późniejszej fazie kształtowania się tego tekstu motywu siódmego dnia odpoczynku Boga; por. Lemański, „Rdz 1,1-2,3 na nowo odczytane?”, 75-84.

Na temat realiów społeczno-politycznych i ekonomicznych panujących w Judzie w okresie po upadku imperium Noeobabilońskiego por. Lipschits, „Demographic Changes”, 323-276.

37 Gertz, Das erste Buch, 68.

38 Lemański, Księga Rodzaju. Rozdziały 1-11, 172; Gertz, Das erste Buch, 68-69.

39 Jan C. Gertz (Das erste Buch, 68 przypis 143) zwraca uwagę na „ważne głosy” w tej dyskusji. Szczegółowe omówienie argumentów w tej debacie (poza ibidem, 70-72) znaleźć można także w: Schellenberg, Der Mensch, 49-59. Omówienie zaś pierwszego z tych czasowników w: Neumann-Gorsolke, Herrschen, 274-300. 
człowieka wprost przełożonym nad zwierzętami. Taki mocny, agresywny i zarazem imperialno-polityczny charakter rozumienia obu czasowników łagodzi jednak bezpośredni kontekst. Kolejne wiersze (ww. 29-30) opisują bowiem raczej pokojową koegzystencje wszystkich żywych stworzeń, a stan ten zmieni się dopiero po potopie (por. Rdz 9,1-7 = P). Człowiek i zwierzęta nie stanowią zatem dla siebie żadnej agresywnej konkurencji. Wynika to również z rozróżnienia w ramach jarskiej diety. Człowiek spożywać ma bowiem rośliny rodzące ziarno i owoce (w. 29), a zwierzęta trawę (w. 30).

Władza, o jakiej tu mowa, ma w tle bliskowschodni obraz władzy królewskiej. Ta ostatnia oceniana była pozytywnie. Głównym zadaniem króla - jak już wspomnieliśmy - było szeroko rozumiane zapewnienie swoim poddanym życia i pokoju oraz obrona przed wszelkiego rodzaju chaosem. Nie zaciera to faktu, że władza sprawowana była często silną ręką i przemocą. Oba aspekty należy brać więc teraz pod uwagę. Człowiek, według P, ma po prostu wykorzystać swoje uzdolnienia w celu spożytkowania natury, wyznaczenia $w$ jej ramach właściwych granic dla siebie i dla zwierząt lądowych. Mamy zatem do czynienia z religijnie umotywowaną legitymizacją ograniczenia bezwzględności w egzekwowaniu nadanej przez Boga władzy i wymogiem sprawiedliwego oraz odpowiedzialnego jej sprawowania. Niewywiązanie się z tego zadania doprowadzi na powrót do chaosu w obrębie stworzenia (por. Rdz 6,9-13).

\subsection{Masculum et feminam}

Wiersz 27 zwiera trzy zdania z dominującym czasownikiem br' - „stworzyć”. Jego ponowne pojawienie się tu po dłuższej przerwie (por. Rdz 1,1.21) wraz z wyraźnym zaakcentowaniem jego roli (użyty jest tu aż trzy razy) podkreśla nie tylko majestatyczny aspekt aktu stworzenia człowieka (tylko Bóg może $b r^{\prime}$ ), ale i dodatkowo jego wyjątkowość. Dwa pierwsze zdania mają układ chiazmu akcentującego fakt, że człowiek stworzony jest „na obraz” Boga. Dopiero jednak trzecie zdanie, pozostające w układzie paralelnym do dwóch poprzednich, rozwija motyw obrazu i dodaje informację, że człowiek został stworzony jako (egzemplarz?) męski i żeński. W istocie P stosuje teraz dwa „pojęcia biologiczne” określające fizjonomicznie aspekt męskości (zākār) i kobiecości ( $\left.n^{e} q e \bar{e} b a ̂\right)$. Zwyczajowe tłumaczenie "mężczyzną i kobietą" stanowi raczej praktyczne rozwinięcie obu pojęć. Takie płciowe rozróżnienie odnosi się zarówno do człowieka (jeszcze w Rdz 5,2), jak i do zwierząt ( $\operatorname{Rdz} 6,19 ; 7,3.9 .16$ ). Choć więc niewątpliwie P ma tu zapewne także na uwadze społeczne zróżnicowanie płci (ang. gender) ${ }^{40}$, to jednak w pierwszym i podstawowym znaczeniu obu użytych terminów - i to należy podkreślić - $\mathrm{P}$ akcentuje przede wszystkim różnice biologiczne i fizjonomiczne. Człowiek został stworzony zatem jako egzemplarz męski i żeński.

40 Podkreślana tu różnica płci w jakimś sensie odzwierciedla także relacyjny charakter człowieka i jego samookreślenie się jako mężczyzna i kobieta; por. Schüle, Die Urgeschichte, 43. 
W istocie w etymologię słowa $z \bar{a} k \bar{a} r$ wpisane jest znaczenie „penis”, zaś w etymologię słowa $n^{e} q e \bar{e} b a ̂$ sens „dziura"41. Obie płcie stworzone są zatem jako imago Dei i obu płciom powierzone jest zadanie panowania na ziemi i nad zwierzętami. Mimo że takie różnice płciowe istnieją również wśród zwierząa ${ }^{42}$, to jednak zostały one stworzone każde według swego rodzaju, podobnie jak rośliny (Rdz 1,11-12.21.24-25). Człowiek - mężczyzna i kobieta - stanowią przedstawicieli wyłącznie jednego gatunku. Tylko on w swojej męskiej i żeńskiej wersji zasługuje na miano imago Dei i zawierzenie mu wspomnianych powyżej zadań. Także tylko to płciowe rozróżnienie ma tu też jakiekolwiek znaczenie w sposobie patrzenia na drugiego człowieka. Akcentuje się tym samym najpierw fakt, że jest ono wyrazem stwórczej woli Boga, a potem także, że stanowi ono uzdolnienie umożliwiające realizację zadania: bycie płodnym i zaludnienie ziemi (w. 28). Ma to potem dalsze konsekwencje. Płciowość stanowi jedyną istotną różnicę pomiędzy ludźmi. Wszystkie inne różnice: geograficzne, antropologiczne, etniczne, rasowe i kulturowe nie stanowią i stanowić nie mogą o większej lub mniejszej godności człowieka (por. Gal 3,28). Co istotne, mężczyzna i kobieta są sobie równi w tej godności.

W układzie kanonicznym takie płciowe rozróżnienie aspektów męskich i żeńskich w człowieku zostaje poszerzone potem w Rdz 5,1-3, gdzie mamy do czynienia $\mathrm{z}$ „pierwszą praparą” ludzi, od której swój początek bierze cała ludzkość. Temat wraca potem jeszcze w Rdz 9,5-6, gdzie zakazane jest zabicie człowieka - obrazu Boga bez rozróżnienia w nim mężczyzny lub kobiety. Przy tej okazji zwrócić należy uwagę na konsekwentność autora biblijnego. W momencie podziału na męski i żeński egzemplarz człowieka następuje zmiana zaimków. Bóg stwarza człowieka na swój obraz, ale stwarza go jako ich - męskiego i żeńskiego (w. 27). Od tego momentu też będzie zwracał się do nich, a nie tylko do niego. Jest to swoiste płciowe rozformowanie człowieka, ale i zaakcentowanie zarazem tej jego dwupłciowej formy. Bóg, który przemówił tu w liczbie mnogiej (w. 26) niezmiennie jest jednym tylko Bogiem (w. 27). Jego imago stanowi zaś równorzędnie mężczyzna i kobieta. Co więcej, stanowią i realizują to imago Dei razem, a nie każde z osobna. Choć w Biblii generalnie nie ma mowy o „płci” Boga, to zwykle mówi się o Nim jak o mężczyźnie. Nie brak także wielu wypowiedzi i porównań do kobiety, zwłaszcza matki (stąd zakaz z Pwt 4,16!). Być może rzecz w tym, że Stwórca - jako dawca życia - odzwierciedla w sobie oba aspekty, choć żaden z nich dosłownie go nie determinuje. Najistotniejsze jest jednak to, że w przypadku człowieka obie płcie, w jednakowym zakresie i z jednakową godnością, razem reprezentują obraz Boga.

41 Por. odpowiednio Ges ${ }^{18}$ II, 302; IV, 842 i 843; DCH III, 110-111; V, 748; KBL I, 258; I, 675. Na ten temat także w: Lemański, Księga Rodzaju. Rozdziały 1-11, 169-170.

42 Poza Rdz 6,19; 7,3.9.16; por. także Wj 13,12 (ogólnie); Wj 13,15; Kpł 1,3.6.10; 4,28.32; 5,6; 22,19 (składane w ofierze). 


\section{Niekapłańska koncepcja antropologiczna (Rdz 2-3)}

Tekst ten był wielokrotnie uzupełniany i poszerzany. Wiele wskazuje, że w swojej podstawowej warstwie literackiej składa się z dwóch niezależnych wcześniej opowiadań - o stworzeniu człowieka $\left(\operatorname{Rdz} 2^{*}\right)$ i o wydarzeniach w ogrodzie/Edenie (Rdz $\left.3^{*}\right)$. Sam opis stworzenia człowieka wydaje się na pierwszy rzut oka lakoniczny. W warstwie podstawowej tekst nawiązuje do znanej choćby z Mezopotamii koncepcji człowieka jako pochodzącego z ziemi (gliny) ${ }^{43}$. W tekście biblijnym (Rdz 2,7) czytamy więc, że człowiek ('ādām) został ukształtowany (jṣr $)^{44}$ przez Boga z ziemi/uprawnej gleby (min-ădāmâ). Prawdopodobnie późniejszy glosator, mając m.in. na uwadze wydarzenia opisane w Rdz 3 (por. Rdz 3,19), rozdzielił oba elementy, umieszczając pomiędzy nimi dodatkowo słowo 'āpār ${ }^{45}$. Jak czytamy dalej, Bóg tchnął w uformowanego z gleby człowieka swój ożywczy oddech (por. Ps 104,30; Hi 27,3) i w ten sposób ten ostatni stał się żywą istotą. W jeszcze dalszej kolejności dowiadujemy się, że ów ożywczy oddech (nišmat hajjim) nie jest tylko przywilejem samego człowieka. Mają go również zwierzęta ( $\mathrm{Rdz} 7,22$ - możliwe jednak, że w P chodzi o późniejsze poszerzenie; por. Ps 150,6; Koh 3,19-21), które tak jak on zasługują na miano żywych istot (nepeš hajjẩ por. Kpł 11,10.46; Ez 47,9; o zwierzętach por. Rdz 1,20.21.24.30). Opis stworzenia jest więc wyraźnie powiązany z pewnego rodzaju „procesem naturalnym"46. Chodzi w nim jednocześnie o jak najściślejsze powiązanie człowieka $\mathrm{z}$ ziemią, a zarazem podkreślenie, że w trakcie stworzenia otrzymał on jednak coś ponadto. Wszystko zachodzi zatem dwuetapowo, w procesie, który można opisać dwumianem: formatio - animatio. Dopiero w wyniku tych dwóch etapów stworzenia powstaje człowiek określony jako „istota żywa” ${ }^{47}$.

Rzeczownik 'àdām występuje tu z rodzajnikiem, ma zatem sens ogólny „ludzie”, choć w obecnym wypadku lepiej powiedzieć „człowiek”. To określenie gatunkowe stosowane jest także później, już po stworzeniu kobiety (por. Rdz 2,25; 3,8: hāa'ādām $w^{e}$-'ištō - „człowiek i jego żona”; 2,23; 3,9: hāa-ādàm). Powiązanie z ziemią/uprawną glebą akcentuje jego stwórcze przeznaczenie: „by uprawiał ziemię” (Rdz 2,5b; 3,19a.23). Dopiero w dalszej fazie kształtowania się tekstu położono akcent na jego przemijalność (stąd wziął się aktualny leksem „proch z ziemi”) ${ }^{48}$. Po tej zmianie w tekście nie chodzi już o materię, z której Bóg stworzył człowieka, ale jego status

\footnotetext{
43 Lemański, Księga Rodzaju. Rozdziały 1-11, 217-219; Gertz, Das erste Buch, 105-106.

44 Czasownik ten ma charakter rzemieślniczy, a dzieło tak wykonane stanowi często wytwór artystyczny (por. Jr 18,4). Często też występuje w parze z czasownikiem 'śh - „zrobić, wyprodukować” (Iz 43,7; 46,11) lub br' - „stwarzać” (tylko Bóg) (Iz 45,7.18; Am 4,13). Z tego ostatniego powodu Bóg także bywa jego podmiotem (Iz 43,21; 49,5).

45 Lemański, Księga Rodzaju. Rozdziały 1-11, 202, 219.

46 Pfeiffer, „Der Baum”, 3.

47 Janowski, Anthropologie, 49.

48 Na ten temat szerzej por. Lemański, „Opis stworzenia”, 5-24; Gertz, Das erste Buch, 100-102.
} 
przed powołaniem do życia (por. Rdz 3,19; Ps 104,29). W Biblii mowa jest o tym, że Bóg jest tym, który podnosi z prochu biedaka (1 Sm 2,8; Ps 113,7). W tej kategoryzacji człowieka przed aktem stwórczym Boga jest więc zapowiedź pewnej dozy dostojeństwa, które otrzymuje on poprzez akt stwórczy, ale zarazem uwydatnienie jego przemijalności i kruchości ${ }^{49}$. To jednak nie zebranie tej, przypominającej konsystencją pył, materii w jedną całość (ukształtowanie ciała), ale dopiero ożywcze tchnienie Boga (por. 2 Sm 22,16; Iz 30,33; Hi 32,8; 33,4 i zwł. Iz 42,5) czyni z tego uformowanego prochu żywą istotę. Brak tego tchnienia sprawia, że człowiek uważany jest za martwego (1 Krl 17,17; Koh 12,7).

Jak można sądzić, pierwszy człowiek mimo wszystko pojmowany jest tu męsko. Widać to zwłaszcza wtedy, gdy naprzeciw niego staje dopiero co stworzona z jego „boku/żebra” kobieta (Rdz 2,23). Autor biblijny za chwilę będzie brał pod uwagę także aspekty społeczno-kulturowe w byciu człowiekiem - mężczyzną (por. Rdz 2,18: nie jest dobrze by był on sam). W obecnym miejscu nie jest on jednak jeszcze uwydatniony.

Opowiadanie o poszukiwaniu „właściwej pomocy” składa się z dwóch zasadniczych części: Bóg stwarza najpierw zwierzęta, pośród których człowiek jednak takiej pomocy nie znajduje (Rdz 2,19-20), a potem - podczas głębokiego snu człowieka-mężczyzny - z jego boku/żebra „buduje” kobietę (Rdz 2,21-23). Etiologiczna w brzmieniu decyzja o byciu razem tej pierwszej pary i deklaracja niewinności (byli nadzy) kończy to opowiadanie o stworzeniu człowieka (Rdz 2,24-25).

\subsection{Nie jest dobre, by człowiek był sam}

Bliska relacja z Bogiem w ogrodzie Eden i stworzenie zwierząt nie niwelują poczucia osamotnienia i tym samym oceny, że nie jest „dobrze”, aby ten stan rzeczy trwał. Ocena ta staje się jeszcze bardziej wymowna w kontekście relacji z Rdz 1, gdzie poszczególne etapy stworzenia wieńczyła formuła ,i widział Bóg, że było dobre”, a po stworzeniu człowieka jako osobników męskiego i żeńskiego całość oceniona została wręcz jako „bardzo dobra”. Tym razem jednak coś „nie jest dobre”. Do swojej pełni człowiek potrzebuje kogoś drugiego, „pomocy” ('ézer) dla siebie ${ }^{50}(\operatorname{Rdz} 2,18$; por. Koh 4,9-12a). Nie o pomoc w pracy (por. Rdz 2,5) jednak tu chodzi, ale o poczucie samotności (por. Rdz 2,18b; potem też 2,23-25) ${ }^{51}$. W Starym Testamencie pojęcie to występuje nade wszystko w kontekście militarnym, w sytuacjach wymagających pomocy. Zwykle też jest wówczas mowa o tym, że udziela jej sam Bóg, który stoi

49 Sarna, Genesis, 17: „both the glory and the insignificance of man”.

50 Leksem $l w$ - „dla niego" $z$ nietypowym dagesz w pierwszej literze oraz formuła wolitywna (w. 18b) wydają się świadomie nawiązywać do Rdz 1,7.16.25, a zwł. do 1,26; por. Fischer, Genesis 1-11, 206. Na temat różnych sposobów interpretacji słowa „pomoc” i danych egzegetycznych por. Napora, „Odpowiednia dla niego pomoc?", 39-41.

51 Schellenberg, Der Mensch, 192. 
przy swoim ludzie (Pwt 33,7.26.29; Ps 121,1-2; 146,5; por. też Wj 18,4: imię jednego z synów Mojżesza). Idea obrony i wsparcia zawarta w tym rzeczowniku w sposób szczególny wyraża się $\mathrm{w}$ tym, że pojawia się on czasem (6 razy) w połączeniu z rzeczownikiem „tarcza” (Pwt 33,29; Ps 33,20). W obecnym kontekście także nie chodzi zatem ani o uzupełnienie w sensie seksualnym (tak św. Augustyn), ani o wspomnianą służebną pomoc w pracy w ogrodzie. Chodzi o coś istotnego, darowanego przez Boga jako wyraz Jego skutecznego wsparcia dla człowieka, aby nie czuł się sam; o dopełnienie jego naturalnych potrzeb (por. Ps 33,20;70,6). Akcent pada na to, że ta „pomoc” ma być „mu”, tj. człowiekowi, „odpowiednia” ( $\left.k^{e} n e g d \hat{o}\right)$. Tak skonstruowany leksem w jego aktualnej formie pojawi się jeszcze tylko raz (w. 20) w całej Biblii Hebrajskiej. Użyty tu w formie prepozycji rzeczownik neged oznacza coś, co jest przeciwległe, odpowiada czemuś, a w tym wypadku stanowi po prostu właściwy odpowiednik ${ }^{52}$. Nie mamy więc do czynienia z jakąkolwiek relacją asymetryczną, lecz z równorzędnym stosunkiem. Chodzi zatem o różnicujące, ale zarazem też niezbędne dopełnienie ludzkiej natury. W aktualnym kontekście tę pomoc należy rozumieć więc jako kogoś w niczym nieustępującego człowiekowi ${ }^{53}$; kogoś, kto wypełni jego samotność swoją obecnością. Innymi słowy: człowiek i potrzebna mu pomoc muszą spotkać się ze sobą na tym samym poziomie potrzeb materialnych, intelektualnych i duchowych. W żadnym elemencie tej wypowiedzi nie ma mowy o relacji poddania kobiety mężczyźnie (por. jednak potem 1 Kor 11,7-12) ${ }^{54}$. Co ciekawe, o stworzeniu kobiety mówi się tu nie w kontekście potrzeby zrodzenia potomstwa, ale właśnie ze względu na zaradzenie owemu poczuciu samotności. Temat ten w sposób szczególny znajduje swoje odzwierciedlenie w tekstach mądrościowych (Syr 6,5-16; 37,1-6) ${ }^{55}$.

\subsection{Zwierzęta jako współstworzenia, lecz pomoc (nie-)odpowiednia (Rdz 2,19-20)}

Człowiek na początku jest więc sam (por. Rdz 32,25). To wyraźny kontrast względem opisu z Rdz 1,27. Chcąc zaradzić temu poczuciu samotności, Bóg stwarza najpierw zwierzęta. Chodzi o „temat poboczny”"56. Mimo wszystko zaskakuje fakt, że Stwórca posługuje się niejako metodą "prób i błędów”. Na pierwszy rzut oka trudno wręcz oprzeć się wrażeniu, że Mu ten pierwszy akt stworzenia „odpowiedniej pomocy” nie wyszed ${ }^{57}$. To jednak błędne rozumienie. Taka technika opowiadania ma na celu jedynie uwydatnienie, na czym ta „odpowiednia pomoc” polega ${ }^{58}$. Podkreśla też auto-

\footnotetext{
KBL I, 627; Schellenberg, Der Mensch, 193.

Tak już von Rad, Das erste Buch, 66.

Por. Gertz, Das erste Buch, 121-122.

Janowski, Anthropologie, 99-102.

Schellenberg, Der Mensch, 203.

Tak m.in. Gunkel, Genesis, 12; Schüle, Die Urgeschichte, 68.

Lemański, Księga Rodzaju. Rozdziały 1-11, 233-234.
} 
nomię człowieka w nadawaniu nazw i ocenie innych żywych stworzeń ${ }^{59}$. To również przejaw inteligencji, która już na tym etapie opisu odróżnia człowieka od zwierząt. Nie ma tu więc mowy o „pomyłce”. Chodzi raczej o budowanie swoistego napięcia przygotowującego na finalny akt stworzenia (kobiety) i zarazem ukazanie w negatywny sposób, czym taka „odpowiednia pomoc" nie jest ${ }^{60}$.

Tak więc Księga Rodzaju, w stylu podobnym do tego z Rdz 2,7, opowiada teraz o tym, że Bóg ukształtował (jṣrr) (por. Rdz 2,7) z ziemi/uprawnej gleby ('ădāmâ) zwierzęta lądowe i ptaki. Nie ma mowy jednak o ożywiającym je, dodatkowym tchnieniu. Nie wspomina się też o morskich stworzeniach. Podobieństwo do stworzenia człowieka wynika z użytej do stworzenia materii, jaką jest ziemia. Dzięki temu informuje jedynie o tym, że zwierzęta i ptaki stają się dla człowieka współstworzeniami, ale niczym więcej (Koh 3,18-21). Człowiek zaraz potem ma nadać im nazwę (w. 19a), czym wyrazi swoją władzę nad nimi, ale też rozpozna w nich tylko i wyłącznie owe współstworzone żywe istoty (w. 20a). Nie znajdzie jednak pośród nich „odpowiedniej dla siebie pomocy" (w. 20b). Ocena jest tu zatem odmienna od tej, która pojawi się za chwilę w reakcji na stworzenie kobiety (w. 23) ${ }^{61}$. To kolejny krok ku indywidualizacji, czy jak określił to Bernd Janowski' ${ }^{62}$, sozialen Geburt”.

\subsection{Kość z mojej kości i ciało z mego ciała (Rdz 2,21-23)}

Sekwencja stworzenia kobiety zaczyna się teraz od głębokiego snu (tardēmâ), w jaki Bóg wprowadził człowieka. W jego trakcie Bóg wyjął z niego żebro (lub bok) (șē̄āa), ranę zasklepił ciałem i zbudował (bnh) z tego, co wyjął kobietę. Sen, o którym mowa, zwykle rozumie się jako rodzaj głębokiego letargu, niemal narkotycznego odrętwienia umysłu, stan ograniczonej świadomości (1 Sm 26,12). Poza Prz 19,15 zawsze słowem tym opisywany jest sen związany z Bogiem. Teologiczne aspekty zastosowania tego rzadkiego określenia snu (tylko 7 razy) są tu o wiele ważniejsze od prób medycznego wyjaśnienia, o jaką fazę snu chodzi. W obecnym miejscu opisuje się nim stan odrętwienia lub nieświadomości w czasie niemal chirurgicznej interwencji Boga dokonanej w ludzkim ciele. $\mathrm{W}$ innych zastosowaniach również zakłada się brak samodzielnej aktywności ze strony ludzi zapadających w taki sen, choć już niekoniecznie brak świadomości (por. Rdz 15,12; Iz 29,10; Hi 4,13; 33,15). Nie zmienia to

\footnotetext{
59 Westermann, Genesis. Kapitel 1-11, 311.

60 Napora, „Odpowiednia dla niego pomoc?”, 42.

61 Motyw pełnego uczłowieczenia poprzez relację z kobietą (w tym wypadku nierządnicą) znajdujemy również w przypadku Enkidu w Eposie o Gilgameszu (Gilgamesz I, 195-198; por. Rdz 3,7). Tam również bohater żył początkowo wśród zwierząt i dopiero relacja ze wspomnianą kobietą wprowadziła go do ludzkiej społeczności.

62 Janowski, Anthropologie, 69-70.
} 
jednak faktu, że ten rodzaj snu czyni z ludzi wyłącznie biernych uczestników całego zdarzenia ${ }^{63}$.

Sam opis stworzenia kobiety odbiega znacząco od tradycyjnych opisów stworzenia człowieka. Nie ma tu mowy o żadnym dodatkowym ożywieniu, a i kobieta pochodzi z ciała/kości człowieka/mężczyzny, a nie z ziemi/uprawnej gleby. Ponadto słowo șelā̄ zwykle oznacza bok konstrukcji architektonicznej, często dla niej kluczowy. Nie mniej często chodzi o element świątyni (1 Krl 6,15-16; por. $1 \mathrm{Krl} \mathrm{7,3})^{64}$. Badacze są więc podzieleni w kwestii, czy w obecnym miejscu to słowo należy tłumaczyć jako „żebro”, czy „bok”65. Stwórca nie przypomina tu już w każdym razie rzemieślnika lepiącego/kształtującego swoje stworzenia, jak garncarz lub kowal swoje wyroby (jṣr; Rdz 2,7: człowiek; 2,19: zwierzęta), lecz budowniczego (bnh). Trzeba zauważyć, że czasownik ten występuje tylko raz w kontekście stworzenia, gdzie opisuje założenie niebiańskiego pałacu (por. Am 9,6). W języku akadyjskim czasownik banûm oznacza już jednak równorzędnie zarówno „stwarzać”, jak i „budować”, stąd znacznie częściej stosowany jest w opisach stworzenia ${ }^{66}$. W języku akadyjskim znajdujemy także dobry ekwiwalent dla słowa șēlā' Jest nim słowo șềīlu $(m)$, mające anatomiczny sens ,żebro" ${ }^{\prime \prime}$. W Biblii obecny tekst to jedyne miejsce, gdzie rzeczownik șēlā przyjmuje takie znaczenie. Niemniej następujące w wersecie 23 entuzjastyczne powitanie („kość z mojej kości...”), a wcześniej także fakt zasklepienia ubytku ciałem, sugerują, że właściwszy jest sens „żebro”. Trudno jednak oprzeć się wrażeniu, że autor biblijny mimo wszystko miał na uwadze zamierzoną dwuznaczność i chciał, by akt stworzenia, tj. zbudowania kobiety, przypominał jednak czytelnikom budowę świątyni ${ }^{68}$.

W opisie nie ma potem wprost mowy o ożywieniu kobiety, choć za chwilę będzie ona uznana za „krzewicielkę życia” (por. Rdz 3,20) ${ }^{69}$. Być może autor biblijny zakłada, że „ciało” wzięte z człowieka (wraz z krwią?) zawiera w sobie już życie. Kobieta zostałaby więc stworzona $\mathrm{w}$ drugim etapie stwarzania człowieka.

Połączenie „żebro” i „życie”, obecny w biblijnym tekście, jak również późniejszy motyw nadania imienia kobiecie (Rdz 3,20) znaleźć można już w sumeryjskim micie „Enki i Ninhursanga”70. W końcowej części tego mitu śmiertelnie chory bóg Enki (zjadł rośliny, które wyrosły z jego nasienia) jest podtrzymywany przy życiu przez Ninhursangę, która stwarza kolejne, niższe rangą bóstwa w reakcji na bolące boga

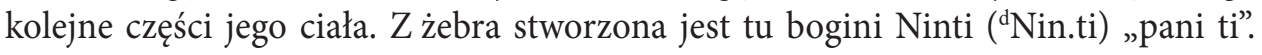

\footnotetext{
63 Lemański, „Rola snów”, 21-27.

64 Lemański, Księga Rodzaju. Rozdziały 1-11, 235. Por. też K. Napora, „Odpowiednia dla niego pomoc?”, 43-44.

65 Na ten temat por. Fischer, Genesis 1-11, 211.

66 CAD II, 83-90, zwł. 87-89 - jako termin stosowany w opisach stworzenia.

$67 \mathrm{Ges}^{18}$ V, 1120; KBL II, 105. Por. też CAD XVI, 124-126.

68 Por. K. Napora, „Odpowiednia dla niego pomoc?”, 43-44.

69 Napora, „'Wąż', ‘życie”, 15-27.

70 Szarzyńska, Mity sumeryjskie, 28-38. Nowsze tłumaczenie TUAT III/3, 363-386.
} 
Znak „ti” w języku sumeryjskim oznacza zarówno „życie” (ak. balātu), jak i „żebro” (ak. șēlu). Problem w tym, że choć paralela jest uderzająca, to jest wątpliwe, aby autor biblijny znał takie podwójne znaczenie sumeryjskiego słowa ${ }^{71}$.

Inna propozycja interpretacyjna sugeruje, aby wszystkie „anomalie” związane z opisem stworzenia kobiety postrzegać w świetle poezji miłosnej z Mezopotamii. W tekstach tego rodzaju po wielokroć znajdujemy przykłady, jak zakochany mężczyzna (głównie w kontekście mitu o Innanie i Dummuzim) opiewa wdzięki swej umiłowanej, patrząc na jej statuetkę wykonaną z delikatnego materiału, zazwyczaj z białej kości. Analogia ta mogłaby wyjaśnić na przykład brak wzmianki o ożywieniu nowostworzonej kobiety ${ }^{72}$. W mezopotamskich pieśniach kobieta opiewana jest jako „żywa statuetka/figurka bogini” (dim.ma.ti.la) i „perfekcyjne dzieło”73. Takie porównanie jest jednak nie tylko $\mathrm{z}$ wielu względów problematyczne, ale i niekonieczne ${ }^{74}$. Owszem, przywołane pieśni mają motyw poetyckiego ożywienia statuetki ukochanej, ale opiewający je kochanek nie wspomina nawet o ich stworzeniu. Wyjątkowe detale obecnego opisu nie wyjaśniają się więc w jakiejś przekonującej analogii znalezionej w tekstach z Lewantu czy z Mezopotamii.

Jak tłumaczyć zatem to, że taki opis stworzenia kobiety wyalienowany jest nawet w kontekście biblijnym? Dobre wyjaśnienie owa „nietypowość” znajduje jednak już w swoim najbliższym kontekście, a ściślej mówiąc, we wspomnianym już radosnym, wręcz entuzjastycznym okrzyku Adama na widok dopiero co stworzonej kobiety ${ }^{75}$. Oto jest ona „kością z mojej kości i ciałem z mego ciała” (w. 23a) - woła pierwszy człowiek. Mamy do czynienia z tzw. „formułą pokrewieństwa”, poprzez którą uznaje się kogoś nieznanego za kogoś bliskiego lub podkreśla takie pokrewieństwo z kimś już znanym (por. Rdz 29,14: Laban i Jakub; potem także 2 Sm 5,1; 19,13.14; 1 Krn 11,1) ${ }^{76}$. Niemniej, co do brzmienia, klasyczna formuła została tu zmodyfikowana na potrzeby wspomnianego kontekstu. Wprowadza ją zwrot „ta dopiero jest...”, który akcentuje, że chodzi tym razem o stworzenie daleko inne niż zwierzęta stworzone i - podobnie jak teraz kobieta - przyprowadzone do człowieka/mężczyzny. Ponadto słowa „kości” i „ciało" zostają tu powtórzone ${ }^{77}$. Dzięki temu uzyskuje się nie tylko podkreślenie ich tożsamościowej jedności, ale zarazem wskazuje na ich jedność przed Bogiem, czego konsekwencją będzie niedługo także wspólne osądzenie obojga w $\operatorname{Rdz} 3^{78}$.

\footnotetext{
71 Bührer, Am Anfang, 229, przyp. 289.

72 Ta propozycja w: Uehlinger, „Eva”, 90-99; idem, „Nicht nur Knochenfrau, 31-34.

73 Uehlinger, „Eva”, 90-92, 98-99.

74 Krytyczne uwagi por. Bührer, Am Anfang, 229, przyp. 290.

75 Tak Bührer, Am Anfang, 229-230; podobnie Gertz, Das erste Buch, 125.

76 Reiser, „Die Verwandtschaftsformel”, 1-4.

77 Krzysztof Napora („Odpowiednia dla niego pomoc?”, 44) zwraca uwagę, że nie chodzi tu tylko o intensyfikację, ale poprzez dodanie przyimka mem o swego rodzaju nowy sens: „pośród moich kości i mojego ciała - ta kobieta zajmuje miejsce pierwsze". 
Nowa sytuacja prowadzi do zmiany także w aspekcie społecznym. Dotąd w miarę neutralny płciowo rzeczownik 'ādām, wraz z odkryciem, że nowostworzona kobieta jest 'iššâ, zostaje zastąpiony przez jej odpowiednik 'iš. Poprzez odkrycie kobiety „swojej odpowiedniej pomocy”, człowiek odkrywa więc siebie jako mężczyznę. Odnajduje w niej już nie kogoś, nad kim ma władzę, lecz kogoś, z kim czuje pokrewieństwo i z kim może nawiązać równorzędne relacje ${ }^{79}$. O ile zatem zwierzęta, jako inne żywe istoty, są postrzegane tu jako współstworzenia - żywe istoty, o tyle kobieta pojmowana jest już jako katalizator pozwalający odkryć dwie odpowiadające sobie i uzupełniające się wzajemnie w wymiarze społecznym strony człowieczeństwa. Odkryciu temu towarzyszy etiologia (w. 24: '́l kēn). Fakt, że deklaracja w niej zawarta, o tym, iż to mężczyzna, a nie kobieta opuszcza dom rodzinny, nie odpowiada realiom (por. $\operatorname{Rdz} 24$ ), budzi jednak wiele dyskusji i znajduje różne wyjaśnienia ${ }^{80}$. Dla jednych opis może wskazywać na siłę uczucia, które łączy mężczyznę i kobietę i powinno być ono ważniejsze niż wszelkie instytucjonalne zasady, a dla innych jest wręcz swego rodzaju zanegowaniem patriarchalnego porządku panującego w ówczesnym społeczeństwie ${ }^{81}$.

Niemniej nie trudno zauważyć, że efektem nietypowej, jak na dotychczasowe standardy, stwórczej aktywności Boga jest w tym wypadku drugi człowiek. Choć akcentuje się teraz, że kobieta jest biologicznie związana z mężczyzną i mu równa, to jednocześnie tym niestandardowym opisem jej stworzenia (zbudowana z żebra, brak ożywiającego tchnienia) zaznacza się, że reprezentuje, mimo tego podobieństwa, coś innego w naturze człowieka. Jednym słowem, w tym opisie akcent jest położony zarówno na to, że coś obie płcie łączy, jak i na to, że coś je od siebie odróżnia. Niemniej to obie płcie razem odzwierciedlają dopiero w pełni ludzką, relacyjną naturę.

Kim był zatem 'ādām zanim nastąpiło to rozróżnienie płci? Septuaginta już od wiersza 16 tłumaczy ten rzeczownik jako imię własne - „Adam”. Tłumacz jest potem konsekwentny w takim rozumieniu tego hebrajskiego rzeczownika (por. Rdz 2,19.23a LXX). W tekście hebrajskim obraz jest jednak inny i praktycznie do wiersza 22 brak jest rozróżnienia płci. Dopiero zmiana, która zachodzi w tym wierszu, pozwala widzieć w słowie 'ādām sens „mężczyzna”" 2 . Nie potrzeba tu jednak spekulować w kwestii, jak autor biblijny mógł rozumieć tego nie „,rozdzielonego” jeszcze na płcie człowieka. Pisząc o ’àdām, miał na uwadze jedynie to, że chodzi właśnie o „człowieka” in statu nascendi. Z drugiej strony trudno oprzeć się wrażeniu, że postrzegał go jednak, mimo wszystko, mając na uwadze trochę bardziej „męski punkt widzenia”.

\footnotetext{
79 K. Napora („Odpowiednia dla niego pomoc?”, 45) słusznie akcentuje w tym miejscu, że poza podkreśleniem pokrewieństwa chodzi tu także o komplementarność.

80 Bührer, Am Anfang, 230-231.

81 Gertz, Das erste Buch, 126.

82 Fischer, Genesis 1-11, 212.
} 


\section{Konkluzja}

Antropologię zawartą w dwóch opisach stworzenia (Rdz 1;2-3) łączy wspólne przekonanie, że człowiek został stworzony jako mężczyzna i kobieta. Tekst kapłański akcentuje jednak bardziej aspekty biologiczne, stosując pojęcia wskazujące na różnice anatomiczne (człowiek jako egzemplarz męski i żeński), zaś tekst niekapłański podkreśla z kolei bardziej rozróżnienie natury społecznej (mężczyzna i kobieta, mąż i żona). W obu opisach stworzenia obecny jest pogląd o równości mężczyzny i kobiety, o ich wzajemnym dopełnianiu się w realizacji powołania Bożego (Rdz 1) i w życiu społecznym (Rdz 2).

Autor kapłański opisuje stworzenie człowieka w sposób majestatyczny (jedyny raz Bóg konsultuje/zastanawia się, mówiąc: „uczyńmy człowieka...”; zastosowanie czasownika $b r^{\prime}$ ) i pojmuje go zarazem jako imago Dei. To idea zapożyczona z bliskowschodniej ideologii królewskiej, rozszerzonej teraz na wszystkich ludzi (należy tu jednak myśleć bardziej o rojalizacji człowieka jako takiego niż demokratyzacji samej idei). Bóg daje człowiekowi uzdolnienie (błogosławieństwo) do reprezentowania Go na ziemi, napełniania jej życiem (płodność) i zagospodarowywania, rozumianego tu jako opanowywanie chaosu i przywracanie stwórczego ładu (imitatio Dei). Zakres zadań i związane z tym reprezentowanie Boga wobec innych żywych stworzeń niezmiennie związane są tu $\mathrm{z}$ faktem, że człowiek stanowi tylko jeden gatunek (inaczej niż zwierzęta), w którym rozróżnialne fizjonomicznie są dwie płcie (inaczej niż Bóg). Obie płcie stanowią tu równorzędnie „obraz i podobieństwo Boga”, obie też równorzędnie realizują wyznaczone człowiekowi zadania. Płodność, która stanowi zadanie fundamentalne (napełnianie ziemi życiem) i umożliwia realizację pozostałych (opanowanie chaosu), pojmowana winna być jednak jako uzdolnienie, dar, a nie nakaz.

Autor niekapłański również zwraca uwagę na status człowieka, ale widzi w nim najpierw proch z ziemi ukształtowany przez Boga i powołany do życia. Opis stworzenia człowieka tym razem podzielony jest na dwa etapy. Pierwszy (Rdz 2,7) przypomina inne bliskowschodnie opisy tego rodzaju. Człowiek powstał z ziemi, aby ją potem uprawiać. Kolejny glosator dodał jednak słowo „proch”, przenosząc akcent na status człowieka - jego przemijalność $(\operatorname{Rdz} 3,19)$. Zarazem podkreślił jednak także jego godność jako kogoś powołanego do istnienia i życia przez Boga. Szybko jednak okazuje się, że w naturę człowieka ('ầām) wpisana jest potrzeba relacyjności, określona tu zwrotem „odpowiednia pomoc”. Bez niej człowiek jest sam, a w ocenie Stwórcy nie jest to dobrze. Mimo że stworzenie człowieka i zwierząt opisane jest w ten sam sposób, wśród tych ostatnich 'ādām nie znajduje „odpowiedniej pomocy”. Odkrywa jedynie, że są one - jak on sam - żywymi istotami, nad którymi ma jednak władzę (nadaje im nazwę) i przewyższa je inteligencją. Odpowiednią pomoc stanowi dopiero kobieta stworzona w drugim etapie tej „, antropogenezy” z żebra/boku 'ādām. To 
ktoś nie tylko w równym stopniu godny bycia postrzeganym jako alter ego ’ādām, ale też niezbędny w byciu nim w pełnym tego słowa znaczeniu. Opis samego aktu stworzenia kobiety jest nietypowy (żebro zamiast ziemi; brak ożywienia). W ten sposób akcentuje jednak biologiczną więź i zarazem dwupłciową różnorodność. Stworzenie kobiety prowadzi nie tylko do odkrycia tych faktów przez 'ādām, ale i uznania/rozpoznania siebie jako mężczyznę mającego naprzeciw siebie kobietę (mąż i żona).

Autorzy biblijni, którzy wypowiadali się na temat relacji homoseksualnych, niewątpliwie byli ludźmi swojej epoki. Ich spojrzenie na to zjawisko było zatem uwikłane w uwarunkowania historyczne i społeczno-kulturowe właściwe ich epoce. W ocenie ich wypowiedzi na ten temat nie można pomijać zatem i tych aspektów. Niemniej u podstaw tych wypowiedzi leży nade wszystko konkretna wizja antropologiczna: człowiek został stworzony i powołany do współpracy z Bogiem jako mężczyzna i kobieta. W relacji mężczyzna - kobieta realizuje się zatem zarówno wspomniane powołanie, jak i w pełnym wymiarze ujawnia się ludzka natura.

Inna sprawa to sposób, w jaki ta antropologiczna wizja z Rdz 1-2 została zaabsorbowana w praktyce. Starożytny Izrael to społeczność głównie rodzinna i agrarna, w której przynależność do rodziny dawała prawa, ale i nakładała obowiązki. Nade wszystko wymagała jednak solidarności w każdym aspekcie życia ${ }^{83}$. Rdz 3 pokazuje, jak ten chciany, pierwotny porządek został zakłócony i w konsekwencji czego ideał nie znalazł potem odbicia w życiu codziennym.

\section{Bibliografia}

Angerstorfer, A., „Ebenbild eines Gottes in babylonischen und assyrischen Keilschrifttexten”, Biblische Notizen 88 (1997) 47-58.

Bührer, W., Am Anfang...Untersuchungen zur Textgenese und zur relativ-chronologischen Einordnung von Gen 1-3 (Forschungen zur Religion und Literatur des Alten und Neuen Testaments 256; Göttingen: Vandenhoeck \& Ruprecht 2014).

Clines, D.J.A. (red.), Dictionary of Classical Hebrew (Sheffeld: Sheffeld Phoenix Press 1993-2011) I-VIII (= DCH)

Desroches Noblecourt, C., Hatszepsut. Tajemnicza królowa Egiptu (tł. J. Karkowski) (Warszawa: Świat Książki 2007).

Fischer, G., Genesis 1-11 (Herders Theologischer Kommentar zum Alten Testament; Freiburg Basel - Wien: Herder 2018).

Frevel, C., „Gottesbildlichkeit und Menschenwürde. Freiheit, Geschöpflichkeit und Würde des Menschen nach dem Alten Testament", Anthropologische Aufbrüche (red. A. Wagner) (Forschungen zur Religion und Literatur des Alten und Neuen Testaments 232; Göttingen: Vandenhoeck \& Ruprecht 2009) 255-274.

83 Janowski, Anthropologie, 93. 
Gertz, J.C., Das erste Buch Mose (Genesis). Die Urgeschichte Gen 1-11 (Das Alte Testament Deutsch 1; Göttingen: Vandenhoeck \& Ruprecht 2018).

Gesenius, W., Hebräisches und Aramäisches Handwörterbuch über das Alte Testament, wyd. 18 (red. H. Donner) (Heildelber - Dordrecht - London - New York: Springer 1987-2012) I-VII $\left(=\right.$ Ges $\left.^{18}\right)$.

Gross, W., „Die Gottebenbildlichkeit des Menschen nach Gen 1,26.27 in der Diskussion des letzten Jahzehnten”, Biblische Notizen 68 (1993) 35-48.

Gross, W., „Gen 1,26.27; Gen 9,6: Statue oder Ebenbild Gottes? Aufgabe und Würde des Menschen nach dem hebräischen und dem griechischen Wortlaut", Jahrbuch für Biblische Theologie 15 (2000) 11-38.

Gross, W. et al., „Image of God”, Encyclopedia of the Bible and Its Reception (red. D.C. Allison H.J. Klauck - C. Helmer) (Berlin: De Gruyter 2016) XII, 885-913.

Gunkel, H., Genesis, wyd. 3 (Handkommentar zum Alten Testament 1/1; Göttingen: Vandenhoeck \& Ruprecht 1910), wyd. 9 (1977).

Hamilton, V.P., The Book of Genesis. Chapters 1-17 (New International Commentary on the Old Testament; Grand Rapids, MI: Eerdmans 1990).

Janowski, B., „Die lebendige Statue Gottes. Zur Anthropologie der priesterlichen Urgeschichte”, Gott und Mensch im Dialog Festschrift für Otto Kaiser zum 80. Geburtstag (red. M. Witte) (Beihefte zur Zeitschrift für die alttestamentliche Wissenschaft 345/1; Berlin - New York: De Gruyter 2004) 183-214.

Janowski, B., Anthropologie des Alten Testaments. Grundfragen - Kontexte - Themenfelder (Tübingen: Mohr Siebeck 2019).

Jenni, E., Die hebräischen Präpositionen. I. Die Präposition Beth (Stuttgart - Berlin - Köln: Kohlhammer 1992).

Kaiser, O. (red.), Texte aus der Umwelt des Alten Testament (Gütersloh: Mohn 1985-1993) I/6, III/3 (= TUAT).

Krüger, T., „Genesis 1:1-2:3 and the Development of the Pentateuch”, The Pentateuch (red. T.B. Dozeman et al.) (Forschungen zum Alten Testament 78; Tübingen: Mohr Siebeck 2011) 125-138.

Lemański, J., „Opis stworzenia jako «conditio humana» w Rdz 2,7?”, Śląskie Studia Historyczno-Teologiczne 39/1 (2006) 5-24.

Lemański, J., Księga Rodzaju. Rozdziały 1-11. Wstęp, przekład z oryginału, komentarz (Nowy Komentarz Biblijny Stary Testament 1/1; Częstochowa: Święty Paweł 2013).

Lemański, J., „Bóg stwarza niebo i ziemię. Pytanie o rolę teologii stworzenia w ramach teologii biblijnej”, Bóg Stwórca (red. A. Paciorek) (Scripturae Lumen 6; Tarnów: Biblos 2014) 13-42.

Lemański, J., Księga Rodzaju. Rozdziały 11,27-36,43. Wstęp - przekład z oryginału - komentarz (Nowy Komentarz Biblijny. Stary Testament 1/2; Częstochowa: Edycja Świętego Pawła 2014) 393-404 [Ekskurs: „Biblia a kwestia homoseksualizmu”].

Lemański, J., „Rdz 1,1-2,3 na nowo odczytane? Czyli pytanie o to, czy możliwe jest nowe spojrzenie na kapłański opis stworzenia?”, Studia Koszalińsko-Kołobrzeskie 23 (2016) 71-105.

Lemański, J., „Rola snów w Księdze Rodzaju (tradycje patriarchalne Rdz 12-36)”, Sny prorockie, sny wieszcze, objawienia Boże poprzez sny w tradycji starotestamentalnej (red. G.M. Baran) (Tarnów: Biblos 2017) 9-45. 
Lemański, J., „Imago Dei. W poszukiwaniu źródeł i znaczenia pewnej biblijnej koncepcji antropologicznej", Powstanie człowieka w ujęciu interdyscyplinarnym (red. T. Maziarka) (Kraków: Copernicus Center Press 2019) 121-154.

Levin, C., Der Jahwist (Forschungen zur Religion und Literatur des Alten und Neuen Testaments 157; Göttingen: Vandenhoeck \& Ruprecht 1993).

Lipschits, O., „Demographic Changes in Judah between Seventh and the Fifth Centuries B.C.E., Judah and the Judeans in the New-Babylonian Period (red. O. Lipschits - J. Blenkinsopp) (Winona Lake, IN: Eisenbrauns 2003) 323-376.

Markschies, C., Gottes Körper. Jüdische, christliche und pagane Gottesvorstellungen in der Antike (München: Beck 2016).

Martin, T.R., Starożytna Grecja. Od prehistorii do czasów hellenistycznych (tł. J. Szkudliński) (Poznań: Wydawnictwo Poznańskie 2016).

Maul, S., „Der assyrische König - Hüter der Weltordnung”, Gerechtigkeit, Richten und Retten in der abendländischen Tradition und ihren altorientalischen Ursprüngen (red. J. Assmann) (München: Fink 1998) 65-77.

Mayer, W.R., „Ein Mythos von der Erschaffung der Menschen und des Königs”, Orientalia NS 56 (1987) 55-68.

McDowell, C.L., The Image of God in the Garden of Eden. The Creation of Humankind in Genesis 2:5-3:24 in Light of mìs pî̀ pit pî and wpt-r Rituals of Mesopotamia and Ancient Egypt (Winona Lake, IN: Eisenbrauns 2015).

Napora, K., „'Wąż, ‘życie’, czy 'matka wszystkiego, co żyje”? Znaczenie imienia hawwâ i jego funkcja w Rdz 3", Niewiastę dzielna kto znajdzie? (Prz 31,10). Rola kobiet w biblijnej historii zbawienia (red. A. Kubiś - K. Napora) (Analecta Biblica Lublinensia 14; Lublin: Wydawnictwo KUL 2016) 15-27.

Napora, K., „Odpowiednia dla niego pomoc? Kobieta w Rdz 1-2”, Sympozjum 21 (2017) 33-48. Neumann-Gorsolke, U., Herrschen in den Grenzen der Schöpfung. Ein Beitrag zur alttestamentlichen Anthropologie am Beispiel von Psalm 8, Genesis 1 und verwandten Texten (Wissenschaftliche Monographien zum Alten und Neuen Testament 101; Neukirchen: Neukirchener Verlag 2004).

Ockinga, B., Die Gottebenbildlichkeit in Ägypten und im Alten Testament (Ägypten und Altes Testament 7; Wiesbaden: Harrassowitz 1984).

Pfeiffer, H., „Der Baum in der Mitte des Gartens. Zum überlieferungsgeschichtlichen Ursprung der Paradieserzählung (Gen 2,4b-3,24), Teil II: Prägende Traditionen und theologische Akzente", Zeitschrift für die alttestamentlische Wissenschaft 113 (2001) 1-16.

von Rad, G., Das erste Buch Mose. Genesis, wyd. 8 (Das Alte Testament Deutsch 2/4; Göttingen: Vandenhoeck \& Ruprecht 1972), wyd. 12 (1987).

Reiser, W., „Die Verwandtschaftsformel in Gen 2,23”, Theologische Zeitschrift 16 (1960) 1-4.

Roth, M.T. (red.), Assyrian Dictionary of the Oriental Institute of the University of Chicago, (Chicago, IL: Oriental Institute 1956-2005) I-XXI (=CAD).

Rüterswörden, U., Dominium terrae. Studien zur Genese einer alttestamentlichen Vorstellung (Beihefte zur Zeitschrift für die alttestamentliche Wissenschaft 215; Berlin - Boston, MA: De Gruyter 1993).

Sarna, N.M., Genesis (JPS Torah Commentary; Philadelphia, PA: Jewish Publication Society of America 1989). 


\section{JANUSZ LEMAŃSKI}

Schellenberg, A., Der Mensch, das Bild Gottes? Zum Gedanken einer Sonderstellung des Menschen im Alten Testament und in weiteren altorientalischen Quellen (Abhandlungen zur Theologie des Alten und Neuen Testaments 101; Zürich: TVZ 2011).

Schroer, S., In Israel gab es Bilder. Nachrichten von darstellender Kunst im Ancient Testament (Orbis biblicus et orientalis 74; Freiburg - Göttingen: Vandenhoeck \& Ruprecht 1987).

Schüle, A., Die Urgeschichte (Genesis 1-11) (Zürcher Bibelkommentare AT 1/1; Zürich: TVZ 2009).

Szarzyńska, K. (tł.), Mity sumeryjskie (Warszawa: Agade 2000).

Uehlinger, C., „Eva als 'lebendiges Kunstwerk”. Traditionsgeschichtliches zu Gen 2,21-22/23.24 und 3,20", Biblische Notizen 43 (1988) 90-99.

Uehlinger, C., „Nicht nur Knochenfrau. Zu einem wenig beachteten Aspekte der zweiten Schöpfungserzählung", Bibel und Kirche 53 (1998) 31-34.

Wagner, A., Gottes Körper. Zur alttestamentlischen Vorstellung der Menschengestaltigkeit Gottes (Gütersloh: Gütersloher 2010).

Wenham, G.J., Genesis 1-15 (The Word Biblical Commentary 1; Dallas, TX: Word Book 1987).

Westermann, C., Genesis. Kapitel 1-11, wyd. 3 (Biblischer Kommentar Altes Testament 1/1; Neukirchen-Vluyn: Neukirchener 1983).

Koehler, L. - Baumgartner, W. - Stamm, J.J. (red.), Wielki słownik hebrajsko-polski aramejski-polski Starego Testamentu (Prymasowska Seria Biblijna 30; Warszawa: Vocatio 2008) I-II (= KBL).

Wildberger, H., „șelem”, Theologisches Handwörterbuch zum Alten Testament (red. E. Jenni C. Westermann) (Gütersloh: Gütersloher Verlaghaus 1976), wyd. 4 (1994) II, 556-563. 